\title{
Proteolytic systems of lactic acid microorganisms: a review
}

\section{Volodymyr Yukalo, Olha Krupa}

\author{
Ternopil Ivan Puluj National Technical University, Ternopil, Ukraine
}

\section{Keywords:}

Proteolysis

Proteinase

Peptidase

Lactic acid

Microorganism

\section{Article history:}

Received

12.04.2017

Received in revised form 23.08.2017

Accepted 05.09.2017

\section{Corresponding author:}

Olha Krupa

E-mail: cmakota@ukr.net

DOI:

$10.24263 / 2304-$

974X-2017-6-3-3

\section{Abstract}

Introduction. The primary objective of this review is to analyze and summarize the existing scientific information about the structure features, formation conditions and properties of proteinases and peptidases of lactic acid microorganisms, which are widely used in the production of dairy products.

Material and methods. The proteolysis of milk proteins, occured by lactic acid microorganisms, is an investigation object of this review article. Scientific articles as well as theses and monographs of microbiology, biochemistry and dairy science have been analysed. Methodology of the investigation is based upon the use of the methods of analysis, comparison and synthesis.

Results and discussion. Cleavage of proteins and amino acids with enzymes of lactic acid and propionic acid bacteria promotes the enrichment of dairy products with nitrogen-containing and nitrogenfree compounds, and as a result, the product obtains necessary consistency, taste and smell. In addition to providing organoleptic properties, the formation of a large number of peptides with different types of biological activity occurs also in the process of proteolysis of milk proteins in the production of dairy products.

The proteolytic system of lactic acid bacteria consists of three parts: proteinases, which that provide the initial cleavage of casein to peptides with formation of a large number of oligopeptides; peptidases, which cleavage peptides to amino acids; transport system, which provides transfer of proteolysis products through the cytoplasmic membrane. Proteinases function outside microbial cells, produce them, and peptidases - in cells of lactic acid bacteria.

By the specificity of the effect on the fractions of the casein complex of milk proteinases of lactic acid microorganisms are divided into 2 types $-P I$ and PIII. Proteinases $P I$ are able to cleavage $\beta$-caseins and don't cleavage $\alpha_{\mathrm{S}^{-}}$and $\kappa$-caseins, but proteinases PIII hydrolyse all three fractions: $\alpha_{S^{-}}, \beta$ - and $\kappa^{-}$ caseins.

None of the peptidases with carboxypeptidase activity were revealed among large number of lactic acid bacteria peptidases. $P e p N, P e p C, P e p A$ are referred to the aminopeptidases, found in lactic acid microorganisms. In addition to aminopeptidase, dipeptidases and tripeptidases were revealed in lactobacilli.

Conclusion. It is recommended to use systematized characteristics of proteinases and peptidases of appropriate microorganisms with the purpose of providing quality organoleptic parameters of dairy products as well as the formation of biologically active peptides in the process of selecting the species composition of starter cultures. 


\section{Introduction}

At production and sale of food and dairy products, in particular, organoleptic properties (taste, smell, consistency) of the finished product are the main factors, which guarantee a high demand level among consumers. Special taste and smell, typical for each product, are provided with various food substances (proteins, fats, carbohydrates) and their cleavage products [1-4]. A significant amount of taste and flavoring substances in dairy products are formed as a result of proteolysis of milk proteins $[1,2,5,6]$. In particular, proteolysis actively occurs in the production of fermented milk products (kefir, koumiss, cottage cheese, etc.). And very intensively - in the production of hard cheeses, in the aging of which there are biochemical changes in milk proteins. Cleavage of proteins and amino acids with enzymes of lactic acid and propionic acid bacteria promotes the enrichment of dairy products with soluble in water nitrogen-containing and nitrogen-free compounds, and as a result, the product obtains necessary consistency, taste and smell [7-14].

In addition to providing organoleptic properties, which are important for the consumer and demand in the market, the formation of a large number of peptides with different types of biological activity occurs also in the process of proteolysis of milk proteins in the production of dairy products [15-17]. Among the casein proteolysis products, bioactive peptides, having opioid affect, antihypertensive and immunomodulating properties, ability to influence blood coagulation processes, transport of calcium ions in the intestine etc., were revealed [18-24]. Inhibitors of angiotensin converting enzyme, peptides with opioid and bactericidal action, immunomodulating and hypocholesterolemic, as well as peptides, affecting intestinal motility, were found among bioactive peptides from milk whey proteins [25-27]. It was defined that $\beta$ - actoglobulin is the precursor of all these types of bioactive peptides, except for immunomodulating peptides. Among bioactive peptides, formed from $\alpha$ - lactalbumin, there are no peptides with hypocholesterolemic action and peptides affecting intestinal motility, and only two types of biological activity are inherent in peptides with lactoferrin (bactericidal and immunomodulating).

It is known that proteolysis of proteins occurs gradually under the influence of lactic acid microorganisms [13]. The casein proteins are the most sensitive to proteolytic enzymes. First the casephosphate complex decomposes into high molecular weight polypeptides, then medium and low molecular weight peptides and amino acids dominate among the products of proteolysis. The majority transformations during the initial stages of proteolysis occur under the influence of extracellular and cell-wall-bound proteinases, and more profound transformations of the peptides - under the influence of membrane and intracellular peptidases of lactic acid bacteria. [28-33].

Lactic acid bacteria (lactococci and lactobacilli), which are a part of different types of starter preparations for dairy products, are auxotrophs, that is, their ability to develop in a dairy medium depends on the activity of the proteolytic system, which ensures the liberation of essential amino acids during the cleavage of proteins of the casein complex, used by microorganisms in the synthesis of proteins [32, 33]. The proteolytic system of lactic acid bacteria consists of three parts:

-proteinases, which that provide the initial cleavage of casein to peptides with formation of

a large number of oligopeptides [32];

-peptidases, which cleavage peptides to amino acids [30];

-transport system, which provides transfer of proteolysis products through the cytoplasmic

membrane $[12,33]$.

It is known that proteinases function outside microbial cells, which produce them, and peptidases - in cells of lactic acid bacteria. 
Proceeding from the aforesaid, the purpose of this work is to analyze and summarize the existing scientific information about the structure features, formation conditions and biochemical properties of proteinases and peptidases of lactic acid microorganisms, which are widely used in the production of dairy products.

\section{Material and methods}

The proteolysis of milk proteins, occured by lactic acid microorganisms, is an investigation object of this review article. Scientific articles as well as theses and monographs of microbiology, biochemistry and dairy science have been analysed. Methodology of the investigation is based upon the use of the methods of analysis, comparison and synthesis. Literature referenced in this review article was obtained from searches from bibliographic information in CAB abstracts, AGRICOLA, SciFinder, Google Scholar, PubMed, ScienceDirect database and Web of Science.

\section{Results and discussion}

\section{Proteinases}

Localization of proteinases. Proteinases of lactic acid microorganisms are monomeric serine proteinases with molecular weight 180000-190000 Da (Table 1), which are connected with the bacterial cell wall and are called extracellular proteinases or in abbreviated form PrtP.

Characteristics of proteinases of lactic acid microorganisms

Table 1

(adapted from Kunji (1996)) [12]

\begin{tabular}{|c|c|c|c|}
\hline $\begin{array}{c}\text { Types and strains of lactic acid } \\
\text { microorganisms }\end{array}$ & $\begin{array}{c}\text { Molecular } \\
\text { weight *, } \\
\text { kDa }\end{array}$ & $\begin{array}{c}\text { Substrate, which is } \\
\text { cleaved with } \\
\text { proteinase }\end{array}$ & $\underset{\text { optimum }}{\text { pH }}$ \\
\hline L. lactis ssp. cremoris WG2 & & $\kappa-, \beta$-caseins & \\
\hline L. lactis ssp. cremoris HP & & $\kappa-, \beta$-caseins & 6,4 \\
\hline L. lactis ssp. cremoris SKII & $187^{n}$ & $\alpha_{\mathrm{S} 1^{-}}, \kappa-, \beta$-caseins & \\
\hline L. lactis ssp. cremoris AC1 & & $\alpha_{S^{-}-}, \kappa-, \beta$-caseins & \\
\hline L. lactis ssp. cremoris AM1 & & $\alpha_{\mathrm{S} 1^{-},}, \kappa-, \beta$-caseins & \\
\hline L. lactis ssp. cremoris $\mathrm{H} 2$ & $180^{\mathrm{e}}$ & $\kappa-, \beta$-caseins & 6,0 \\
\hline L. lactis ssp. cremoris NCD0763 & & $\alpha_{S 1^{-},} \kappa-, \beta$-caseins & \\
\hline Lb. casei ssp. casei $\mathrm{NH} 14$ & & $\beta$-casein & \\
\hline Lb. casei ssp. casei NCD0151 & & & 6,5 \\
\hline Lb. delbrueckii ssp. bulgaricus CNRZ397 & $170^{\mathrm{e}}$ & $\alpha_{\mathrm{S} 1^{-}}, \beta$-caseins & 5,5 \\
\hline Lb. helveticus CNRZ303 & & $\alpha_{\mathrm{S}^{-}}, \beta$-caseins & 7,5 \\
\hline Lb. helveticus CP709 & $45^{\mathrm{e}}$ & $\alpha_{\mathrm{S} 1^{-}}, \beta$-caseins & 6,5 \\
\hline Lb. helveticus L89 & $180^{\mathrm{e}}$ & $\alpha_{\mathrm{S} 1^{-}}, \beta$-caseins & 7,0 \\
\hline
\end{tabular}

Notes: The molecular weight of the enzyme was defined with polyacrylamide gel electrophoresis (mark-e) or calculated by the primary structure (mark-n). 
Primary PrtP structure and the structure of gene, which encodes their synthesis [12, 34], was defined for most types of lactic acid microorganisms. Thus, in lactococci and $L b$. paracasei cell-wall-bound proteinase includes 1902 amino acid residues in Lb. delbrueckii - 1946, and in Lb. lactis - 1962. Primary PrtP structure in different lactococci is identical for $98 \%$ and is identical for $95 \%$ with $L b$. paracasei. The analysis of the primary structure of proteinases shows their similarity with subtilisins, which are also serine proteinases with similar catalytic domains [35]. Wherein, $\mathrm{N}$-end part of the formed enzyme contains a catalytic domain with several conserved amino acid residues, which participate in the catalytic process and substrate binding. The next segment shows no similarity to proteins with similar functions and, evidently, is responsible for placing the catalytic domain on the surface of the cell wall [35]. C- terminal part of cell-wall-bound proteinases is similar to that found in many Gram-positive bacteria and includes signal sequence and $\alpha$ - helix section, connected with the membrane [36].

Extracellular localization of proteinases is possible in cases of microorganisms placing in the solutions without calcium [37], or when microorganism cells are exposed to enzyme lysozyme affect [38]. In the first case, the enzyme is formed with less molecular weight $(165000 \mathrm{Da})$ in comparison with lysozyme affect (180000 Da), which can happen due to auto-proteolysis.

In the laboratory of biochemistry of dairy products of Ternopil Ivan Puluj National Technical University, it has been obtained the evidence of the existence of cell-wall-bound extracellular proteases in St. salivarius ssp thermophilus (strain $9_{1}$ ) during proteolysis of purified casein fractions by microorganism cells [39].

Substrate specificity of proteinases. Some authors defined, that cell-wall-bound proteinases are characterized with wide substrate specificity [37, 40, 41]. Those sectors, on which proteolysis uniquely occurs, were not defined on the basis of analysis of many products of proteolysis. Only those sectors were found, which were sensitive mainly to the affect of different types of proteinases. It should be noted, that di- and tripeptides, as well as free amino acids are formed in small quantities under affect of cell-wall-bound proteinases of lactic acid bacteria on $\alpha_{\mathbb{S}^{-}}, \beta$ - and $\kappa$-caseins. However, many slightly larger peptides are formed (4-8 amino acid residues), which contain all essential amino acids, necessary for normal growth of lactic acid bacteria. All products of proteolysis, formed due to the affect of cell-wall-bound proteinases, are located in the medium, outside the bacterial cell.

By the specificity of the effect on the fractions of the casein complex of milk cell-wallbound proteinases of lactic acid microorganisms are divided into 2 types - PI and PIII. Proteinases $P I$ are able to cleavage $\beta$-caseins and don't cleavage $\alpha \mathrm{S} 1$ - and $\kappa$-caseins, but proteinases $P I I I$ hydrolyse all three fractions: $\alpha_{s^{-}}, \beta$ - and $\kappa$-caseins $[12,32,44]$.

Cleavage of $\beta$-casein fraction with proteinases. Recently they conduct intensive research for the purpose of detailed study of caseins proteolysis products with cell-wallbound proteinases of lactobacilli. It was established that $\beta$-caseins are the most sensitive to the affect of these enzymes. Specificity of the proteinases activity at incubation the purified casein fraction with intact bacterial cells was studied in the early works [42]. At the same time it was proved, that only cell-wall-bound proteinase shows proteolytic action. Later in the experiments in vitro they used purified enzymes obtained from various strains of lactic acid bacteria, and the appropriate fraction of casein. In particular, they investigated the influence of cell-wall-bound proteinase of lactic acid microorganisms $L$. lactis and $L b$. helveticus on $\beta$-casein [43]. They separated the products of $\beta$-casein proteolysis by liquid chromatography method, purified and installed the primary structure by Edman. The first results showed that only part of $\beta$-casein is cleavageted under affect of cell-wall-bound proteinase. In this case, large fragments are mainly formed. Further research, using liquid 
chromatography method under high pressure and mass spectrometry, allowed to analyze more than $95 \%$ peptides, formed at $\beta$-casein cleavageting with proteinase of $P I$ type [40]. More than 100 peptides, consisting of 4-30 amino acid residues were found. Most peptides contained 4-10 residues.

It was established that half of the peptides is formed from $C$ - terminal part of $\beta$-casein molecule. Analysis of products of $\beta$-casein proteolysis, formed under the affect of proteinase of the type PIII, allowed to identify thirteen identical links, which are always cleavageted with proteinases of the type PIII and PI, and six links, which are often cleavageted with cell-wall-bound proteinases of bacteria of different strains. The aforesaid peptides are formed mainly from $\mathrm{C}$ - terminal part of $\beta$-casein molecule. In addition to the proteinases, typical for Lb. helveticus and L. lactis in Lb. helveticus CP790, much smaller cell-wall-bound proteinase ( $45000 \mathrm{Da})$, which belongs to the class of serine proteinases and shows specificity in relation to $\beta$-casein [43], was also revealed.

Cleavage of $\alpha_{S I^{-}} i \alpha_{S 2^{-}}$-casein fractions_occurs mainly due to the affect of PIII-type proteinases or mixed-type proteinases. Proteinases $P I$ do not hydrolyze the fractions of $\alpha_{S^{-}}$ caseins [44]. 25 main oligopeptides, half of which is formed as a result of C-terminal part cleavageting, were identified among the products of proteolysis, [41, 45]. Besides, the number of small peptides, formed from sectors, adjoining to peptide connections, sensitive to proteinase, were identified.

The analysis of specificity of proteinases Exterkate F.A., Albing A.C., Bruinenberg P.G. [34] was conducted on the fragment of $\alpha_{\mathrm{S}_{1}}$-casein, including amino acid residues 1-28. In this case, they used proteinases, extracted from sixteen different $L$. lactis strains. Based on the results of these studies, they separated proteinase of lactococcus into 7 groups, which differed in the specificity of cleavageting of the aforesaid fragment of $\alpha_{\mathrm{S} 1}$-casein. Comparison of amino acid sequences responsible for substrate binding, of proteases with different specificity showed, that their specificity is caused by minor genetic variations of the structural proteinase gene. The primary structure of the catalytic domain is conservative not only in lactococci, but also in lactobacilli with cell-wall-bound proteinases. So, in Lb. paracasei two substitutions of amino acid residues in this domain were found, and in Lb. delbrueckii - three substitutions [46]. In proteinase Lb. helveticus (strain L89) the same specificity as in the proteinase lactococci was revealed. Differences between them were due to different ratios of proteolysis products [47].

Cleavage of $\kappa$-casein fraction with proteinases. Products of proteolysis of $\kappa$-casein were studied under the influence of cell-wall-bound proteinase of different types in the number of strains of lactococcus L. lactis [41, 48, 49]. Cleavage of $\kappa$-casein causes the formation of large number of small peptides predominantly from C- terminal part of molecule. Most peptide connections are constantly subjected to hydrolysis with all types of proteinases, however, the peptides were also found, which are formed under affect of certain types of specific proteinases.

\section{Peptidases}

Peptidases - are the enzymes of hydrolase class, which cleavage one by one amino acid from the carboxyl or amine end from peptide molecules. There are many works in the scientific literature, devoted to structure, properties and specificity of peptidases, main results of which are systematized in the Table 2 . 
Peptidases of lactic acid microorganisms (adapted from Kunji (1996)) [12]

\begin{tabular}{|c|c|c|c|c|c|}
\hline $\begin{array}{l}\text { Name of the } \\
\text { enzyme }\end{array}$ & Substrate & $\begin{array}{l}\text { Strain of lactic acid } \\
\text { microorganisms }\end{array}$ & 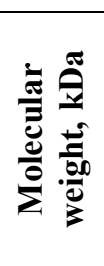 & $\begin{array}{l}\text { Quaternary } \\
\text { structure }\end{array}$ & $\begin{array}{l}0 \\
0 \\
0 \\
0 \\
0 \\
0 \\
0 \\
0 \\
0 \\
0 \\
0 \\
0 \\
0\end{array}$ \\
\hline \multirow{11}{*}{$\begin{array}{l}\text { Aminopeptidases } \\
\mathbf{N} \\
\text { PepN }\end{array}$} & \multirow[t]{11}{*}{$\mathrm{X} \downarrow(\mathrm{X})_{\mathrm{n}}$} & $\begin{array}{l}\text { L. lactis ssp. cremoris } \\
\text { Wg2 }\end{array}$ & 95 & monomer & $\mathrm{M}$ \\
\hline & & $\begin{array}{l}\text { L. lactis ssp. cremoris } \\
\text { MG1363 }\end{array}$ & 95 & & \\
\hline & & $\begin{array}{l}\text { L. lactis ssp. cremoris } \\
\text { HP }\end{array}$ & 95 & & \\
\hline & & $\begin{array}{l}\text { Lb. casei ssp.casei } \\
\text { LGG }\end{array}$ & 87 & monomer & $\mathrm{M}$ \\
\hline & & $\begin{array}{l}\text { Lb. casei ssp. casei } \\
\text { IFPL731 }\end{array}$ & 95 & monomer & $\mathrm{M}$ \\
\hline & & $\begin{array}{l}\text { Lb. delbrueckii ssp. } \\
\text { lactis DSM7290 }\end{array}$ & 95 & monomer & $\mathrm{M}$ \\
\hline & & $\begin{array}{l}\text { Lb. delbrueckii ssp. } \\
\text { bulgaricus } \mathrm{B} 14\end{array}$ & 95 & monomer & $\mathrm{M}$ \\
\hline & & Lb. helveticus ITGL1 & 97 & monomer & $\mathrm{M}$ \\
\hline & & Lb. helveticus SBT2171 & 95 & monomer & $\mathrm{M}$ \\
\hline & & Lb. sanfrancisco CB1 & 75 & monomer & $\mathrm{M}$ \\
\hline & & $\begin{array}{l}\text { S. salivarius ssp. } \\
\text { thermophilus CNRZ302 }\end{array}$ & 97 & monomer & M \\
\hline \multirow{5}{*}{$\begin{array}{l}\text { Aminopeptidases } \\
\text { C } \\
\text { PepC }\end{array}$} & \multirow[t]{5}{*}{$\mathrm{X} \downarrow(\mathrm{X})_{\mathrm{n}}$} & $\begin{array}{l}\text { L. lactis ssp. cremoris } \\
\text { AM2 }\end{array}$ & 50 & hexamer & $\mathrm{C}$ \\
\hline & & $\begin{array}{l}\text { Lb. delbrueckii ssp. } \\
\text { lactis DSM7290 }\end{array}$ & 51 & & $\mathrm{C}$ \\
\hline & & $\begin{array}{l}\text { Lb. delbrueckii ssp. } \\
\text { bulgaricus } \mathrm{B} 14\end{array}$ & 54 & tetramer & $\mathrm{C}$ \\
\hline & & Lb. helveticus CNRZ32 & 50 & & $\mathrm{C}$ \\
\hline & & $\begin{array}{l}\text { S. salivarius ssp. } \\
\text { Thermophilus }\end{array}$ & 50 & hexamer & $\mathrm{C}$ \\
\hline \multirow{3}{*}{$\begin{array}{l}\text { Aminopeptidases } \\
\text { A } \\
\text { PepA }\end{array}$} & \multirow[t]{3}{*}{$\mathrm{X} \downarrow(\mathrm{X})_{\mathrm{n}}$} & $\begin{array}{l}\text { L. lactis ssp. cremoris } \\
\text { AM2 }\end{array}$ & 40 & hexamer & $\mathrm{M}$ \\
\hline & & $\begin{array}{l}\text { L. lactis ssp. cremoris } \\
\text { MG1363 }\end{array}$ & 38 & & \\
\hline & & $\begin{array}{l}\text { S. salivarius ssp. } \\
\text { Thermophilus }\end{array}$ & 45 & octomer & $\mathrm{M}$ \\
\hline
\end{tabular}


Continue of the Table 2

\begin{tabular}{|c|c|c|c|c|c|}
\hline $\begin{array}{l}\text { Name of the } \\
\text { enzyme }\end{array}$ & Substrate & $\begin{array}{l}\text { Strain of lactic acid } \\
\text { microorganisms }\end{array}$ & 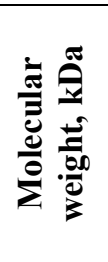 & $\begin{array}{l}\text { Quaternary } \\
\text { structure }\end{array}$ & 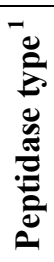 \\
\hline $\begin{array}{l}\text { Dipeptidases V } \\
\text { PepV }\end{array}$ & $\mathrm{X} \downarrow \mathrm{X}$ & $\begin{array}{l}\text { L. lactis ssp. cremoris } \\
\text { Wg2 }\end{array}$ & 49 & monomer & \\
\hline \multirow{9}{*}{$\begin{array}{l}\text { Dipeptidases D, } \\
\text { PepD }\end{array}$} & \multirow[t]{9}{*}{$X \downarrow X$} & $\begin{array}{l}\text { L. lactis ssp. cremoris } \\
\text { MG1363 }\end{array}$ & 51 & & $\mathrm{M}$ \\
\hline & & $\begin{array}{l}\text { L. lactis biov. } \\
\text { Diacetilactis }\end{array}$ & 50 & & $\mathrm{M}$ \\
\hline & & $\begin{array}{l}\text { Lb. delbrueckii ssp. } \\
\text { lactis DSM7290 }\end{array}$ & 52 & & $\mathrm{M}$ \\
\hline & & $\begin{array}{l}\text { Lb. delbrueckii ssp. } \\
\text { bulgaricus } \mathrm{B} 14\end{array}$ & 51 & monomer & $\mathrm{M}$ \\
\hline & & $\begin{array}{l}\text { Lb. helveticus } \\
\text { SBT } 2171\end{array}$ & 50 & monomer & $\mathrm{M}$ \\
\hline & & $\begin{array}{l}\text { Lb. casei ssp. casei } \\
\text { IFPL731 }\end{array}$ & 46 & monomer & $\mathrm{M}$ \\
\hline & & Lb. sace & 50 & monomer & $\mathrm{M}$ \\
\hline & & Lb. sanfrancisco CB1 & 65 & monomer & $\mathrm{M}$ \\
\hline & & Lb. helveticus $53 / 7$ & 54 & octomer & $\mathrm{T}$ \\
\hline $\begin{array}{l}\text { Tripeptidases } \\
\text { PepT }\end{array}$ & $\mathrm{X} \downarrow \mathrm{X}-\mathrm{X}$ & $\begin{array}{l}\text { L. lactis ssp. cremoris } \\
\text { Wg2 }\end{array}$ & 52 & dimer & $\mathrm{M}$ \\
\hline \multirow[t]{3}{*}{ Prolidases Q PepQ } & \multirow[t]{3}{*}{$\mathrm{X} \downarrow$ Pro } & $\begin{array}{l}\text { L. lactis ssp. cremoris } \\
\text { AM2 }\end{array}$ & 52 & dimer & $\mathrm{M}$ \\
\hline & & $\begin{array}{l}\text { L. lactis ssp. cremoris } \\
\text { IMN-C12 }\end{array}$ & 23 & trimer & $\mathrm{C}$ \\
\hline & & $\begin{array}{l}\text { L. lactis ssp. cremoris } \\
\text { AM2 }\end{array}$ & 42 & monomer & $\mathrm{M}$ \\
\hline \multirow{5}{*}{$\begin{array}{l}\text { X- rolyldipeptidyl- } \\
\text { aminopeptidase } \\
\text { PepX }\end{array}$} & \multirow{5}{*}{$\begin{array}{l}X-\operatorname{Pro} \downarrow \\
(X)_{n}\end{array}$} & $\begin{array}{l}\text { Lb. delbrueckii ssp. } \\
\text { lactis DSM7290 }\end{array}$ & 41 & & $\mathrm{M}$ \\
\hline & & $\begin{array}{l}\text { Lb. delbrueckii ssp. } \\
\text { Bulgaricus }\end{array}$ & 41 & & $\mathrm{M}$ \\
\hline & & $\begin{array}{l}\text { Lb. delbrueckii ssp. } \\
\text { bulgaricus CNRZ }\end{array}$ & 41 & dimer & \\
\hline & & $\begin{array}{l}\text { Lb. casei ssp. casei } \\
\text { IFPL731 }\end{array}$ & 41 & monomer & $\mathrm{M}$ \\
\hline & & L. lactis ssp. lactis $\mathrm{H} 1$ & 83 & dimer & $\mathrm{S}$ \\
\hline
\end{tabular}


Continue of the Table 2

\begin{tabular}{|c|c|c|c|c|c|}
\hline $\begin{array}{l}\text { Name of the } \\
\text { enzyme }\end{array}$ & Substrate & $\begin{array}{l}\text { Strain of lactic acid } \\
\text { microorganisms }\end{array}$ & 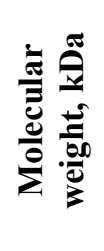 & $\begin{array}{l}\text { Quaternary } \\
\text { structure }\end{array}$ & 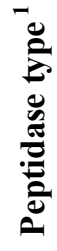 \\
\hline \multirow{11}{*}{$\begin{array}{l}\text { Prolineimmuno- } \\
\text { peptidases } \\
\text { PepI }\end{array}$} & \multirow{11}{*}{$\begin{array}{l}\text { Pro } \downarrow X- \\
(X)_{n}\end{array}$} & $\begin{array}{l}\text { L. lactis ssp. cremoris } \\
\mathrm{P}-8-2-47\end{array}$ & 90 & & $\mathrm{~S}$ \\
\hline & & $\begin{array}{l}\text { L. lactis ssp. cremoris } \\
\text { AM2 }\end{array}$ & 59 & dimer & $\mathrm{S}$ \\
\hline & & $\begin{array}{l}\text { L. lactis ssp. cremoris } \\
\text { nTR }\end{array}$ & 88 & dimer & $\mathrm{S}$ \\
\hline & & $\begin{array}{l}\text { Lb. casei ssp. casei } \\
\text { LLG }\end{array}$ & 79 & & $\mathrm{~S}$ \\
\hline & & $\begin{array}{l}\text { Lb. delbrueckii ssp. } \\
\text { lactis DSM7290 }\end{array}$ & 88 & & $\mathrm{~S}$ \\
\hline & & $\begin{array}{l}\text { Lb. delbrueckii ssp. } \\
\text { bulgaricus } \mathrm{B} 14\end{array}$ & 95 & dimer & $\mathrm{S}$ \\
\hline & & Lb. helveticus 53/7 & 91 & dimer & $\mathrm{S}$ \\
\hline & & Lb. helveticus LHE-51 & 87 & & $\mathrm{~S}$ \\
\hline & & $\begin{array}{l}\text { Lb. helveticus } \\
\text { CNRZ32 }\end{array}$ & 90 & & $\mathrm{~S}$ \\
\hline & & $\begin{array}{l}\text { S. salivarius ssp. } \\
\text { thermophilus ACA-DC4 }\end{array}$ & 80 & dimer & S \\
\hline & & $\begin{array}{l}\text { L. lactis ssp. cremoris } \\
\text { HP }\end{array}$ & 50 & & $\mathrm{M}$ \\
\hline \multirow{4}{*}{$\begin{array}{l}\text { Endopeptidases } \\
\text { Pep E }\end{array}$} & & $\begin{array}{l}\text { Lb. delbrueckii ssp. } \\
\text { lactis DSM7290 }\end{array}$ & 33 & & $\mathrm{~S}$ \\
\hline & & $\begin{array}{l}\text { Lb. delbrueckii ssp. } \\
\text { bulgaricus CNRZ }\end{array}$ & 33 & & $\mathrm{~S}$ \\
\hline & & Lb. helveticus 53/7 & 34 & dimer & $\mathrm{S}$ \\
\hline & & $\begin{array}{l}\text { Lb. helveticus } \\
\text { CNRZ32 }\end{array}$ & 52 & & $\mathrm{C}$ \\
\hline Pep G & & $\begin{array}{l}\text { Lb. delbrueckii ssp. } \\
\text { lactis DSM7290 }\end{array}$ & 50 & & $\mathrm{C}$ \\
\hline Pep O & & $\begin{array}{l}\text { Lb. helveticus } \\
\text { CNRZ32 }\end{array}$ & 71 & & $\mathrm{M}$ \\
\hline \multirow[b]{2}{*}{ PepF1,PepF2 } & & L. lactis & 71 & & $\mathrm{M}$ \\
\hline & & L. lactis & 70 & & \\
\hline
\end{tabular}

${ }^{I}$ Note. $M$ - metalopeptidase; $S$-serine; $C$-cysteine peptidase. 
Peptidases localization. The question of the peptidases localization in the cells of lactic acid bacteria has been changed since the time of its rising. In earlier works it was written about their localization on cell membranes and even outside the cells [13]. At present most researchers tend to think about intracellular localization of all peptidases of lactic acid microorganisms [50-53]. The absence of signal sequences and anchor sections for fixation on the membrane in all peptidases, for which the primary structure was established, can be the evidence of this. Besides, transport system of oligopeptides of lactic acid bacteria can provide entering of large peptides, formed with casein proteolysis, into the cell. And there is no need to cleavage peptides outside the cell or on cell membranes.

Substrate specificity of peptidases. In accordance with the effect on substrates, we can distinguish

- aminopeptidases, hydrolyzing the peptide connection, formed by the amino group of the polypeptide chain and the carboxyl group of the terminal amino acid,

- carboxypeptidases, acting on the peptide connection, formed by the carboxyl group of the polypeptide chain and the amino group of the final amino acid,

- dipeptidases, which provide hydrolysis of dipeptides.

None of the peptidases with carboxypeptidase activity were revealed among large number of lactic acid bacteria peptidases, different by specificity. PepN, PepC, PepA are referred to the aminopeptidases, found in lactic acid microorganisms. In addition to aminopeptidase, dipeptidases $P e p D$ and $P e p V$ [50, 52] were revealed in lactobacilli.

Aminopeptidase $N(P e p N)$._Study of genes $P e p N$ in different bacteria showed a high level of their identity [50], at the same time the primary structure $P e p N$ is homologous to aminopeptidase $\mathrm{N}$ in mammals [54]. PepN can cleavage off $\mathrm{N}$-end amino acids in di- and tripeptides. However, dipeptides, which contain proline residue in the first or second positions, are not cleavageted with $P e p N$, whereas such connection in tripeptides undergoes hydrolysis [55,56]. PepN dipeptides better the hydrolyses, in which N-end amino acid residue is arginine. Dipeptides, containing lysine and leucine in the first position, are hydrolyzed less [57]. The enzyme activity increases with increasing of hydrophobicity Cend amino acid residue of dipeptide $\operatorname{Arg}-\mathrm{X}$. PepN with Lb. helveticus has similar properties with respect to dipeptides Ala-X and Lei-X [55].

The affect of $P e p N$ on oligopeptides was studied in several works [56,57]. PepN ability to cleavage oligopeptides, including from 4 to 14 amino acid residues, is shown on the example of using products of trypsin hydrolyzate of $\beta$-casein as a substrate. It was found that hexapeptide is the optimal substrate for PepN [57]. Aminopeptidase $\mathrm{N}$ with $L b$. helveticus is capable of hydrolyze the peptides, containing up to 10 amino acids, at that, the proline residue may be in the first position. It is also known that the enzyme is capable to sptil the end tyrosine from the fragment $\beta$-CNf 193-209, containing 16 amino acid residues [58].

Regulation of PepN expression in L. lactis depends on the bacterial strain, as well as from the nutrient medium [50]. At lactococci growth in milk the $P e p N$ activity is higher than at growth on artificial nutrient media. It is known that the dipeptide Pro-Lei reduces PepN expression in L. lactis MG1363 [59]. They used the mutants of Lb. helveticus and L. lactis with deletion of the gene pepN $[58,60]$ in order to clarify the physiological role of peptidase $\mathrm{N}$. Slight reduction of lactobacilli growth in the dairy medium was revealed, whereas difference in their growth was not revealed on the artificial complex nutrient medium. Similarly, mutants and wild strains $L$. lactis grow on the artificial nutrient medium, however they grow much more slowly in milk media.

Aminopeptidase $C$ (PepC)_was defined from many strains of lactic acid bacteria [50,61]. They established high activity of $\operatorname{PepC}$ at cleavageting the peptide connections, 
created with basic (Arg, Gis, Liz), acidic (Glu, Asp), hydrophobic (Ala, Lei) and aromatic (Fen) amino acids. At the same time the connections, formed with the proline of the type: Pro-pNA, Pro- $\beta$ NAP, X-Pro- pNA, X-Pro- $\beta N A P$, remained discontinuous. Structural modeling of PepC with L.lactis showed that $\mathrm{C}$-terminal residues, participating in the interaction of $\alpha$-carboxyl group PepC and $\alpha$-amino group of the substrate [62], are the part of the enzyme active center. This was also confirmed at studying of the mutants without $\mathrm{C}$ terminal residue PepC. The mutants L. lactis with deletion of the gene PepC did not lag behind in growth in nutrient medium, but in milk they decreased by $10 \%[60]$.

Aminopeptidase A (PepA) is able to cleavage off acidic N-terminal amino acid residues, to hydrolyse well Glu- and Asp-pNA and much less Glu- and Asp- $\beta N A P$ [63,64]. PepA is able to cleavage off $\mathrm{N}$-terminal Glu and Asp in peptides of different sizes (from 2 to 10 residues). The mutants $L$. lactis, in which there is no PepA, somewhat lag behind in growth at lag- phase, but in the final version they reach the same concentration as in wild strains.

X-prolyl-peptidyl-aminopeptidase (PepX). X-prolyl-dipeptidyl-aminopeptidase (PepX), which cleavages off dipeptides of type $\mathrm{X}-\mathrm{O}$ with $\mathrm{N}$-terminal part of peptides was found in strains of many kinds of lactic acid bacteria. Besides, PepX shows amidase and esterase activity $[65,66]$. The highest activity of $P e p X$ is revealed at cleavageting of X-o-PNA substrates, in which N-terminal amino acid is not charged (Ala, Gly) or is basic (Arg). It is known that $P e p X$ does not hydrolyze dipeptides, but cleavages peptides, including from 3 to 7 amino acid residues [65-67]. Dipeptides, which are released under PepX affect, can contain residues of basic amino acids (Arg, Gis, Liz), aromatic (Fen, Tir) and hydrophobic (Ala, Ile, Val, Gli) amino acids in the first position. PepX specificity to substrates of the type X-Ala- $(\mathrm{X})_{\mathrm{n}}$ was established and obtained at cleavageting of two dipeptides Liz-Ala and Val-Pro [66,67], using the fragment of $\beta$-casein $f$ 176-182 (Liz-Ala-Val-Pro-Tir-ProGln). Besides, Pep $X$ is able to hydrolyze the substrates of the type Pro-Pro- $(\mathrm{X})_{\mathrm{n}}$, but almost does not cleavage X-Pro-Pro [51].

The original aminopeptidase $P e p P$, which releases N-terminal amino acids from the peptides of the type X-Pro-Pro-(Y) $)_{\mathrm{n}}[68,69]$, was found only in lactococci L. lactis. PepP showed the highest activity for pentapeptides, including from 3 to 9 amino acid residues. PepP specificity towards the next N-terminal amino acids (X): Arg, Met, Liz, Lei and Tir was established. Difference in the growth rate in artificial and dairy medium of the mutants with deletion gene PepP and wild strains $L$. lactis is small.

Dipeptidases. Dipeptidase PepD has a wide specificity, but does not hydrolyze AApNA, dipeptides, containing proline residues, and dipeptides with N-terminal remains of glycine. In contradistinction to PepD, peptidase PepV is more important for lactic acid bacteria growth. It was shown on the example of L. lactis, that strains, which didn't contain $P e p V$, lagged behind in growth in $22 \%$ [70].

Proline-iminopeptidase (PepI), which cleavages off $\mathrm{N}$-terminal proline residue in peptides, is common among lactic acid bacteria. [70,71]. PepI shows hydrolytic activity to peptides of type Pro-X, where X may be a hydrophobic residue (Ala, Ile, Lei, Val), acidic (Glu) or aromatic residue (Fen, Tir). Use of peptides of different sizes as substrates showed, that PepI mainly cleavages off $\mathrm{N}$ - terminal proline in di- and tripeptide (rarely in tetrapeptide, for example, Pro-Fen-Gli-Liz), but not in pentapeptides [72]. By its specificity PepI of lactococci and lactobacilli differ between themselves: PepI of lactococci metalopeptidase, and PepI of lactobacilli - serine. The absence of proline-iminopeptidase in the mutants with deletion gene PepI does not affect their growth in complex artificial nutrient medium. Wherein The time of doubling of microorganisms in dairy medium is increased by $9 \%$. 
Peptidase, which cleavages off $\mathrm{N}$ - terminal amino acid, when the second position is the proline residue - prolidase $(P e p Q)$ [53, 73]. Prolidase is enzyme, which hydrolyses dipeptide X-Pro. However, not all of the prolidase are dipeptidases, and they are capable to hydrolyze not all substrates of the type X-Pro. First of all Pep $Q$ hydrolyses dipeptides, which in the first position contain residues of hydrophobic (Ala, Ile, Lei, Val), main (GIS), aromatic (Fen, Tir) and sulfur-containing (Met) amino acids. Some prolidases show an incomprehensible high ability to cleavage peptides without residues of proline, or contained it in the first position (Pro-Ala, Pro-Pro, Pro-Val). In a dairy medium the strains $L b$. helveticus, with PepQ deficit, developed by $13 \%$ slower. Study of bacteria strains, in which PepQ functions normally, and strains without this enzyme showed, that almost $100 \%$ dipeptides Met- Pro, Lei-Pro and Fen-Pro are hydrolyzed with PepQ participation.

Tripeptidases. Tripeptidase PepT, separated from L. lactis, hydrolyses tripeptides, except peptides of the type X-Pro-Y. They are not able to hydrolyze di-, tetra- or large peptides [74]. Other tripeptidases are characterized by greater ability to cleavage tripeptides with hydrophobic and aromatic amino acid residues $[75,76]$. Physiological role of PepT was studied little. It is only known that PepT absence in lactococci delays their growth in milk [60].

Peptidase $P$ epO cleavages oligopeptides, which include from 5 to 35 amino acid residues [76-78]. Like thermolysin, $P$ epO hydrolyses peptide connections, are formed with leucine and phenylalanine. Though $P e p O$ cleavages a series of casein fragments, the native proteins of the casein complex are not hydrolyzed. Growth of mutants with deletion gene $P e p O$ and wild strains $L b$. helveticus were examined in various nutrient medium [77]. They observed a slight lag in growth of mutants L.lactis, using milk as a nutrient medium [60].

One more peptidase $(P e p F)$, which cleavages the oligopeptides, was found only in лактококки [79]. PepF hydrolyzes the oligopeptides, which include from 5 to 17 amino acid residues [79]. PepF shows the highest cleavageting ability for substrates, consisting of 8 or 9 residues. $P e p F$ hydrolyses three connections, releasing peptides from 3 to 5 residues in the fragment AKTG (f 1-24). Lack of activity of PepF towards $\beta$-chain of insulin (30 residues), glucagon (29 residues) and the fragment AKTG (f 1-24) allows you to determine the limits of substrates size (less than 24 residues). $P e p F$ doesn't cleavage native proteins of the casein complex of proteinase. This enzyme plays an important role in the processes of lactococci growth in a dairy medium. Generation time of the mutants with lack of PepF increases by $16 \%$ [9].

\section{Conclusion}

Based on the analysis of scientific sources, it is established that microorganisms widely used in technologies of dairy products, can produce a number of proteases (proteinases and peptidases), which play important role in proteolytic processes of industrial production of protein dairy products - primary cleavageting of the casein complex proteins and release of amino acids from exogenous peptides. Proteinases function outside microbial cells, which produce them, and peptidases - in the cells of lactic acid bacteria. In most cases, the mutants, deficient in each of the peptidases, do not differ in their growth from wild strains of lactobacilli in complex artificial nutrient media, and in a dairy medium they significantly lagged behind in growth.

It is recommended to use systematized characteristics of proteinases and peptidases of appropriate microorganisms with the purpose of providing quality organoleptic parameters of dairy products as well as the formation of biologically active peptides in the process of selecting the species composition of starter cultures. 


\section{References}

1. Nozhechkina G.N. (2013), Formirovanie organolepticheskikh pokazatelei tverdykh syrov. Faktory sozrevaniia tverdykh syrov, Molochnaia industriia, 1, pp. 28-30.

2. Gorbatova K.K., Gunkova P.I. (2012), Khimiia i fizika moloka i molochnykh produktov, GIORD, Sankt-Peterburg.

3. Kuznetsov V.V., Shiler G.G. (2003), Spravochnik tekhnologa molochnogo proizvodstva. Tom 3. Syry, GIORD, Sankt-Peterburg.

4. Stepanova L.I. (1999), Spravochnik tekhnologa molochnogo proizvodstva. Tom 1. Tselnomolochnye produkty, GIORD, Sankt-Peterburg.

5. Ardö Y. (2006), Flavour formation by amino acids catabolism, Biotechnology Advances, 24, pp. 238-242

6. Marilley L., Casey M.G. (2004), Flavours of cheese products: Metabolic pathways, analytical tools and identification of producing strains, International Journal of Food Microbiology, 90, pp. 139159.

7. Ordiales E., Martín A., Benito M. J. (2013), Role of the microbial population on the flavor of the soft-bodied cheese Torta del Casar, Journal of Dairy Science, 96(9), pp. 5477-5486.

8. Sgarbi E., Lazzi C., Tabanelli G. (2013), Nonstarter lactic acid bacteria volatilomes produced using cheese components, Journal of Dairy Science, 96(7), pp. 4223-4234.

9. Nardi M., Renault P., Monnet V. (1997), Duplication of pep F and shuffling of DNA fragments on the lactose plasmid of Lactococcus lactis, Journal of Bacteriology, 179, pp. 41644171.

10. Fernández M., Zuniga M. (2006), Amino acid catabolic pathways of lactic acid bacteria, Critical Reviews in Microbiology, 32, pp. 155-183.

11. Helinck S., Le Bars D., Moreau D., Yvon M. (2004), Ability of thermophilic lactic acid bacteria to produce aroma compounds from amino acids, Applied and Environmental Microbiology, 70, pp. 3855-3861.

12. Kunji E.R.S, Mierau I., Hagting A., Poolman B., Konings W.N. (1996), The proteolytic systems of lactic acid bacteria, Antonie Van Leeuwenhoek, 70(2-4), pp.187-221.

13. Thomas T.D., Pritchard G. (1987), Proteolytic enzymes of dairy starter cultures, FEMS: Microbiology Rewieves, 46 (3), pp. 245-268.

14. Bergamini C.V., Peralta G.H., Milesi M.M., Hynes E.R. (2013), Growth, survival, and peptidolytic activity of Lactobacillus plantarum I91 in a hard-cheese model, Journal of Dairy Science, 96 (9), pp. 5465-5476.

15. Algaron, F., Miranda, G., Le Bars, D., Monnet, V. (2004), Milk fermentation by Lactococcus lactis with modified proteolytic systems to accumulate potentially bio-active peptides, Lait, 84, 115-123.

16. Yukalo, V.H., Storozh, L.A. (2017), Obtaining of casein phosphopeptides under the influence of proteolytic systems of Lactococci, Scientific Messenger LNUVMBT named after S.Z. Gzhytskyj, 19 (75), pp. 50-54.

17. Iukalo, A.V., Storozh, L.A., Yukalo, V.H. (2012), Proteiny kazeinovoho kompleksu moloka koriv (Bos taurus) yak poperednyky biolohichno aktyvnykh peptydiv, Biotekhnolohiia, 5(4), pp. 21-33.

18. Haque E., Chand R., Kapila S. (2009), Biofunctional Propeties of Bioactive Peptides of Milk Origin, Food Reviews International, 25 (1), pp. $28-43$.

19. Nagpal R., Behare P., Rana R., Kumar A., Kumar M., Arora S., Morotta F., Jain S., Yadav H. (2009), Bioactive peptides derived fron milk proteins and their health beneficial potentials: an update, Food \& Function, 2 (1), pp. 18-27.

20. Szwajkowska M., Wolanciuk A., Barlowska J., Król1 J., Litwińczuk Z. (2011), Bovine milk proteins as the source of bioactive peptides influencing the consumers' immune system - a review, Animal Science Papers and Reports, 29 (4), pp. 269-280.

21. Lopes-Fandino R., Otte J., van Camp J. (2006), Physiological, chemical and technological aspects of milk-protein-derived peptides with antihypertensive and ACE-inhibitory activity, International Dairy Journal, 16(11), pp. 1277-1293. 
22. Gobbetti M., Stepaniak L. De Angelis M., Corsetti A, Di Cagno R. ( 2002), Latent bioactive peptides in milk proteins: proteolytic activation and significance in dairy processing, Critical Reviews in Food Science and Nutrition, 42 (3), pp. 223-239.

23. Sieber R, Butikofer U, Egger C, Portmann R, Walther B, Wechsler D. (2010), ACE-inhibitory activity and ACE-inhibiting peptides in different cheese varieties, Dairy Science \& Technology, 90 (1), pp. 47-73.

24. Iukalo A. V., Datsyshyn K. Ye., Yukalo V. G. (2013), Bioactive peptides of the cow milk Whey proteins (bos taurus), Biotekhnolohiia, 6(5), pp. 49-61.

25. Madureira A. R., Tavares T., Gomes A. M. P., Pintado M.E., Malcata F. X. ( 2010), Phisiological properties of bioactive peptides obtained from whey proteins, Journal of Dairy Science, 93 (2), pp. $437-455$.

26. Gauthier S. F., Pouliot Y., Saint-Sauveur D. (2006), Immunomodulatory peptides obtained by the enzymatic hydrolysis of whey proteins, International Dairy Journal, 16 (11), pp. 1315-1323.

27. Sadat-Mekmene L., Richoux R., Aubert-Frogerais L., Madec M.-N., Corre C., Piot M., Jardin J., le Feunteun S., Lortal S., Gagnaire V. (2013), Lactobacillus helveticus as a tool to change proteolysis and functionality in Swiss-type cheeses, Journal of Dairy Science, 96 (3), pp. 1455-1470.

28. Ferreira I.M., Pinho O., Monteiro D., Faria S., Cruz S., Perreira A., Roque A.C., Tavares P. (2010), Effect of kefir grains on proteolysis of major milk proteins, Journal of Dairy Science, 93(1), pp. $27-31$.

29. Silva S.V., Malcata F.X. (2005), Caseins as source of bioactive peptides, International Dairy Journal, 15, pp. 1-15

30. Christensen J.E., Dudley E.G., Pederson J.A., Steele J.L. (1999), Peptidase and amino acid catabolism in lactic acid bacteria, Antonie van Leeuwenhock, 76, pp. 217-246.

31. Zhang S, Zhang L, Han X. (2015), Lactic acid bacteria proteinase and quality of fermented dairy products. A review, Wei Sheng Wu Xue Bao,. 55(12), pp. 1530-1536.

32. Savijoki K, Ingmer H, Varmanen P (2006), Proteolytic systems of lactic acid bacteria, Applied Microbiology and Biotechnology, 71(4), pp. 394-406.

33. Law B.A., Haandrikman A. (1997), Proteolytic enzymes of lactic acid bacteria, International Dairy Journal, 7(1), pp. 1-11.

34. Exterkate F.A., Albing A.C., Bruinenberg P.G. (1993), Diversity of cell envelope proteinase specificity among strains of Lactococcus lactis and its relationship to charge characteristics of the substrate-binding region, Applied and Environmental Microbiology, 59, pp. 3640-3647.

35. Andrews A T, Varley J. (1994), Biochemistry of milk products, Royal Society of Chemistry, Cambridge.

36. Navarre W.W., Schneewind O. (1994), Proteolytic cleavage and cell wall anchoring at the LPXTG motif of surface proteins in Gram-positive bacteria, Molecular Microbiology, 14 (1), pp. 115-121.

37. Takafuji S., Iwasaki T., Sasaki M., Tan P.S.T. (1995), Proteolytic enzymes of lactic acid bacteria, Developments in Food Science, 37, pp. 753-767.

38. Coolbear T., Reid J.R., Pritchard G.G. (1992), Stability and specificity of the cell wall associated proteinase from Lactococcus lactis ssp. cremoris $\mathrm{H} 2$ released by treatment with lysozyme in the presence of calcium ions, Applied and Environmental Microbiology, 58, pp. 3263-3270.

39. Yukalo V.H. (2007), Bilky kazeinovoho kompleksu koroviachoho moloka ta produkty yix proteolizu za dii fermentiv molochnokyslykh bakterii, Instytuti biolohii tvaryn UAAN, Lviv.

40. Juillard V., Laan H., Kunji E.R.S. (1995), The exstracellulur P1-type proteinase of Lactococcus lactis hydrolyzes $\beta$-casein into more then one hundred different oligopeptides, Journal of Bacteriology, 177, pp. 3472-3478.

41. Monnet V., Ley J.P., Gonzalez S. (1992), Substrate specificity of the cell envelope-located proteinase of Lactococcus lactis subsp. lactis NCDO 763, International Journal of Biochemistry, 24, pp. 707-718. 
42. Exterkate F.A., De Veer G. (1985), Partial isolation and degradation of caseins by cell wall proteinase of S. cremoris HP, Applied and Environmental Microbiology, 49 (2), pp. 328-332.

43. Yamamoto N., Akino A., Takano T. (1993), Purification and specificity of cell-wall-associated proteinase from Lactobacillus helveticus CP 790, The Journal of Biochemistry, 114, pp. 740-745.

44. Visser S., Extercate F.A., Slangen C.J., De Veer G.J.M. (1986), Comparative study of action of cell wall proteinases from various strains of Streptococcus cremoris on bovine $\alpha_{\mathrm{S} 1}-, \beta-\kappa$-casein, Applied and Environmental Microbiology, 52, pp. 1162-1166.

45. Reid J.R., More C.N., Midwinter G.G., Pritchard G.G. (1991), Action of a cell wall proteinase from Lactococcus lactis ssp. cremoris SK11 on bovine $\alpha_{\mathrm{s}_{1}}$-casein, Applied Microbiology and Biotechnology, 35, pp. 222-227.

46. Holch A., Nas H. (1992), Cloning, sequencing and expression of gene encoding the cellenvelopeassociated proteinase from Lactobacillus paracasei subsp. paracasei NCDO 151, Journal of General Microbiology, 138, pp. 1353-1364.

47. Martin-Hemandez M.C., Alting A.C., Exterkate F.A. (1994), Purification and characterization of the mature, membrane-associated cell-envelope proteinase of Lactobacillus helveticus L 89, Applied Microbiology and Biotechnology, 40, pp. 828-834.

48. Reid J.R., Coolbear T., Pillidge C.J., Pridchard G.G. (1994), Specificity of hydrolysis of bovine $\kappa-$ casein by cell envelope-associated proteinases from Lactococcus lactis strains, Applied and Environmental Microbiology, 60, pp. 801-806.

49. Visser S., Slangen C.J., Robben A.J.P.M., van Dongen W. D., Heerma W., Haverkamp J. (1994), Action of a cell - envelope proteinase ( $\mathrm{CEP}_{\mathrm{II}}-$ type $)$ from Lactococcus lactis subsp. cremoris AM1 on bovine $\kappa$-casein, Applied Microbiology and Biotechnology, 41, pp. 644-651.

50. Rawlings N. D, Barrett A.J., Woessner J. F. (2012), Handbook of Proteolytic Enzymes: 3rd Edition, Elsevier: Academic Press.

51. Stressler T, Eisele T., Schlayer M. (2013), Characterization of the recombinant exopeptidases PepX and PepN from Lactobacillus helveticus ATCC 12046 important for food protein hydrolysis, PLoS One, 8(7), e70055. doi: 10.1371/journal.pone.0070055.

52. Luoma S., Peltoniemi K., Joutsjoki V., Rantanen T., Tamminen M., Heikkinen I., Palva A. (2001), Expression of six peptidases from Lactobacillus helveticus in Lactococcus lactis, Applied and Environmental Microbiology, 67, pp. 1232-1238.

53. Yang S.I., Tanaka T. (2008), Characterization of recombinant prolidase from Lactococcus lactischanges in substrate specificity by metal cations, and allosteric behavior of the peptidase, The FEBS journal, 275, pp. 271-280.

54. Tan P.S.T., Van Alen-Boerrigter J.J., Poolman B. (1992), Characterization of the Lactococcus lactis pep $\mathrm{N}$ gene encoding an aminopeptidase homologous to mammalian aminopeptidase $\mathrm{N}$, FEBS Lett, 306, pp. 9-16.

55. Miyakawa H., Kobayashi S., Shimamura S. et al. (1992), Purification and characterization of an aminopeptidase from Lactobacillus helveticus LHE-511, Journal of Dairy Science, 75 (1), pp. 27 35.

56. Tan P.S.T., Van Kessel T.A., Van de Veerdonk (1993), Degradation and debittering of a tryptic digest from $\beta$-casein by aminopeptidase $\mathrm{N}$ from Lactococcus lactis subsp. cremoris Wg 2, Applied and Environmental Microbiology, 59, pp. 1430-1436.

57. Niven G.W., Holder S.A., Stroman P. (1995), A study of the substrate specificity of aminopeptidase N from Lactococcus lactis subsp. cremoris, Applied Microbiology and Biotechnology, 43, pp. 91-97.

58. Christensen J.E., Steele J.L. (1996), Characterization of peptidase-deficient Lactobacillus helveticus CNRZ 32 derivatives, Fifth Symposium on Lactic Acid Bacteria, The Netherlands, Veldhoven, pp. 391-397.

59. Marugg J.D., Meijer W., Van Kranenburg (1995), Medium-dependet regulation of proteinase gene expresion in Lactococcus lactis: control of transcription initiation by specific dipeptides, Journal of Bacteriology, 177, pp. 2982-2989. 


\section{- Food Technology -}

60. Mireau I., Kunji E.R.S., Leenhouts K.J. (1996), Multiple-peptidase mutants of Lactococcus lactis are severely impaired in their ability to grow in milk, Journal of Bacteriology, 178, pp. 2794-2803.

61. Mistou M.Y., Gripon J.C. (1998), Catalytic properties of the cysteine aminopeptidase PepC, a bacterial bleomycin hydrolase, Biochimica et Biophysica Acta, 3, pp. 63-70.

62. Mata L., Erra-Pujada M., Gripon J.C., Mistou M.Y. (1997), Experimental evidence for the essential role of the $\mathrm{C}$-terminal residue in the strict aminopeptidase activity of the thiol aminopeptidase Pep C a bacterial bleomycin hydrolase, Biochemical Journal, 328, pp. 343-347.

63. Bacon C.L., Jennings P.V., Fhaolain I.N., O'Cuinn G. (1994), Purification and characterization of an aminotripeptidase A from cytoplasm of Lactococcus lactis subsp. cremoris AM2, International Dairy Journal, 4, pp. 503-519.

64. Rul F, Monnet V. (1997), Presence of additional peptidases in Streptococcus thermophilus CNRZ 302 compared to Lactococcus lactis, Journal of Applied Microbiology, 82(6), pp. 695-704.

65. Hafeez Z., Cakir-Kiefer C., Girardet J.M., Jardin J., Perrin C., Dary A., Miclo L. (2013), Hydrolysis of milk-derived bioactive peptides by cell-associated extracellular peptidases of Streptococcus thermophilus, Applied Microbiology and Biotechnology, 97, pp. 9787-9799.

66. Gatti M., Fornasari M.E., Lazzi C. (2004), Peptidase activity in various species of dairy thermophilic lactobacilli, Journal of Applied Microbiology, 96(2), pp. 223-229.

67. Kimura K., Nagasawa A., Fujii M. (2002), Cloning of the pepX gene of Lactobacillus helveticus IF03809 encoding salt-tolerant X-prolyl dipeptidyl aminopeptidase and characterization of the enzyme, Journal of Bioscience and Bioengineering, 93, pp. 589-594.

68. Stressler T., Eisele T., Schlayer M. (2012), Production, active staining and gas chromatography assay analysis of recombinant aminopeptidase P from Lactococcus lactis ssp. lactis DSM 20481, AMB Express, doi: 10.1186/2191-0855-2-39.

69. Mc Donnell M., Fitzgerald R., Fhaoláin I.N. et al. (1997), Purification and characterization of aminopeptidase P from Lactococcus lactis subsp. cremoris, Journal of Dairy Research, 64, pp. 399-407.

70. Fitz G.R.J., Meisel H. (2000), Milk protein-derived peptide inhibitors of angiotensin-I-converting enzyme, British Journal of Nutrition, 84, pp. 33-37.

71. Wegmann U., Klein J.R., Drumm I. et al. (1999), Introduction of peptidase genes from Lactobacillus delbrueckii subsp. lactis into Lactococcus lactis and controlled expression, Applied and Environmental Microbiology, 65(11), pp. 4729-33.

72. Baankreis R., Exterkate F.A. (1991), Characterization of a peptidase from Lactococcus lactis ssp. cremoris HP that hydrolyses di- and tripeptides containing proline or hydrophobic residues as a amino-terminal amino acid, Systematic and Applied Microbiology, 14, pp. 317-323.

73. Morel F., Frot-Coutaz J., Aubel D. (1999), Characterization of a prolidase from Lactobacillus delbruckii ssp. bulgaricus CNRZ 397 with an unusual regulation of biosynthesis, Microbiology, 145, pp. 437-446.

74. Bacon C.L., Wilkinson M., Jeninings P.V., Fhaolain I.N., O'Cuinn G. (1993), Purification and characterization of an aminotripeptidase from cytoplasm of Lactococcus lactis subsp. cremoris AM2, International Dairy Journal, 3 (2), pp. 163-177.

75. Mori S., Sumino S., Kasumi T. (2002), Substrate specificity of a tripeptidase as a metalloenzyme purified from Lactococcus lactis subsp. lactis biovar. diacetylactis ATCC 13675, Journal of Bioscience and Bioengineering, 93, pp. 360-366.

76. Chen Y.S., Steele J.L. (1998), Genetic characterization and physiological role of endopeptidase O from Lactobacillus helveticus CNRZ 32, Applied and Environmental Microbiology, 64, pp. 34113415.

77. Chen Y.S., Christensen J.E., Broadbentet J.R. et al. (2003), Identification and characterization of Lactobacillus helveticus $\mathrm{PepO}_{2}$, an endopeptidase with post-proline specificity, Applied and Environmental Microbiology, 69, pp. 1276-1282. 
78. Janer C., Arigoni F., Lee B.H.et al. (2005), Enzymatic ability of Bifidobacterium animalis subsp. lactis to hydrolyze milk proteins: identification and characterization of endopeptidase O, Applied and Environmental Microbiology, 71, pp. 8460-8465.

79. Monnet V., Nardi M., Chopin A. (1994), Biochemical and genetic characterization of Pep F, an oligopeptidase from Lactococcus lactis, The Journal of Biological Chemistry, 269, pp. 3207032076 . 